11 - ORIGINAL ARTICLE Experimental Models

\title{
Effects of prone and supine position on oxygenation and inflammatory mediator in a hydrochloric acid-induced lung dysfunction in rats ${ }^{1}$
}

\author{
Efeitos da posição prona e supina na oxigenação e mediador inflamatório na disfunção \\ pulmonar induzida por ácido clorídrico em ratos
}

\begin{abstract}
Wagner Rogério Souza de Oliveira', Ivaldo da Silva ${ }^{\mathrm{II}}$, Ricardo Santos Simões ${ }^{\mathrm{III}}$, Luiz Fernando Portugal Fuchs ${ }^{\mathrm{III}}$, Ricardo Martins Oliveira-Filho ${ }^{\mathrm{IV}}$, Itamar Souza de Oliveira-Júnior ${ }^{\mathrm{V}}$
\end{abstract}

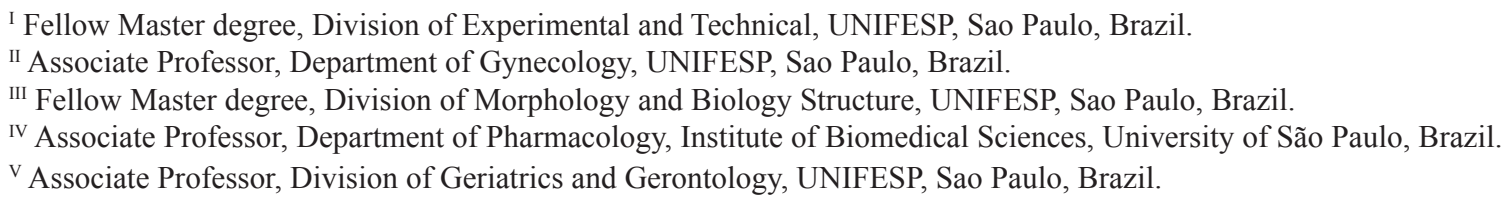

\section{ABSTRACT}

Purpose: To compare the effectiveness of mechanical ventilation of supine versus prone position in hydrochloric acid (HCl)-induced lung dysfunction. Methods: Twenty, adult, male, Wistar-EPM-1 rats were anesthetized and randomly grouped ( $\mathrm{n}=5$ animals per group) as follows: CS-MV (mechanical ventilation in supine position); CP-MV (mechanical ventilation in prone position); bilateral instillation of $\mathrm{HCl}$ and mechanical ventilation in supine position $(\mathrm{HCl}+\mathrm{S})$; and bilateral instillation of $\mathrm{HCl}$ and mechanical ventilation in prone position $(\mathrm{HCl}+\mathrm{P})$. All groups were ventilated for 180 minutes. The blood partial pressures of oxygen and carbon dioxide were measured in the time points 0 (zero; 10 minutes before lung injury for stabilization), and at the end of times acid injury, 60,120 and 180 minutes of mechanical ventilation. At the end of experiment the animals were euthanized, and bronchoalveolar lavages (BALs) were taken to determine the contents of total proteins, inflammatory mediators, and lungs wet-to-dry ratios. Results: $\mathrm{In}$ the $\mathrm{HCl}+\mathrm{P}$ group the partial pressure of oxygen increased when compared with $\mathrm{HCl}+\mathrm{S}(128.0 \pm 2.9 \mathrm{mmHg}$ and $111.0 \pm 6.7 \mathrm{mmHg}$, respectively) within $60 \mathrm{minutes}$. TNF- $\alpha$ levels in BAL do not differ significantly in the $\mathrm{HCl}+\mathrm{P}$ group $(516.0 \pm 5.9 \mathrm{pg} / \mathrm{mL})$, and the $\mathrm{HCl}+\mathrm{S}(513.0 \pm 10.6 \mathrm{pg} / \mathrm{mL})$.

Conclusion: The use of prone position improved oxygenation, but did not reduce TNF- $\alpha$ in BAL upon lung dysfunction induced by $\mathrm{HCl}$.

Key words: Lung. Respiration, Artificial. Oxygenation. Inflammation Mediators. Rats.

\section{RESUMO}

Objetivo: Comparar os efeitos da ventilação mecânica em posição prona versus supina na disfunção pulmonar induzida por ácido clorídrico $(\mathrm{HCl})$. Métodos: Vinte ratos, adultos, Wistar-EPM-1 foram anestesiados e distribuídos aleatoriamente em grupos (n=5 animais por grupo): CS-MV (controle, ventilado mecanicamente em posição supina); CP-MV (controle, ventilado mecanicamente em posição prona); instilação bilateral de $\mathrm{HCl}$ e ventilação mecânica em posição supina $(\mathrm{HCl}+\mathrm{S})$ ou ventilação em posição prona $(\mathrm{HCl}+\mathrm{P})$. Todos os grupos foram submetidos a ventilação mecânica por 180 minutos. As pressões parciais de oxigênio e dióxido de carbono no sangue arterial foram mensuradas nos tempos Injúria ácida (10 minutos após instilação de $\mathrm{HCl}$ ), e ao final de cada período após lesão por $\mathrm{HCl}$, 60, 120 e 180 minutos sob ventilação mecânica. Ao final do experimento os animais foram eutanasiados, os pulmões retirados para avaliação do peso úmido em relação ao peso seco do pulmão direito e realizamos o lavado broncoalveolar (BAL) para determinação de proteínas totais e o mediador inflamatório TNF- $\alpha$. Resultados: No grupo $\mathrm{HCl}+\mathrm{P}$ a pressão parcial de oxigênio, no tempo de 60 minutos, aumentou quando comparada com o grupo $\mathrm{HCl}+\mathrm{S}(128.0 \pm 2.9$ e $111.0 \pm 6.7 \mathrm{mmHg}$, respectivamente). Os níveis de TNF- $\alpha$ no lavado broncoalveolar não diferiram de maneira estatisticamente significante quando comparamos os grupos $\mathrm{HCl}+\mathrm{S}(513.0 \pm 10.6 \mathrm{pg} / \mathrm{mL})$ versus $\mathrm{HCl}+\mathrm{P}(516.0 \pm 5.9 \mathrm{pg} / \mathrm{mL})$. Conclusão: $\mathrm{O}$ uso da posição prona melhora a oxigenação, mas não reduz os níveis de BAL após disfunção pulmonar induzida por $\mathrm{HCl}$.

Descritores: Pulmão. Respiração Artificial. Oxigenação. Mediadores da Inflamação. Ratos.

${ }^{1}$ Research performed at Experimental Surgery Center, Department of Surgery, Federal University of Sao Paulo (UNIFESP), Brazil. 


\section{Introduction}

Gastric acid aspiration is a common etiology of acute lung injury (ALI) and is initially characterized by a chemical "burn" of the pulmonary epithelium, with a subsequent influx of extracellular fluid into the alveolar space that leads to pulmonary edema. Hence, acid aspiration-content is an important cause of acute respiratory distress syndrome (ARDS) ${ }^{1}$.

Acute lung injury (ALI) and ARDS are serious complications in trauma and surgical patients ${ }^{2,3}$. In spite of improvements in critical care and ventilator management, mortality rates have been reported to remain as high as $35 \%$ to $40 \%{ }^{4,5}$.

A variety of ventilatory maneuvers are employed to combat it, such as mechanical ventilation with prone and/or supine position, positive end expiratory pressure (PEEP), alveolar recruitment, high-frequency ventilation and non-ventilatory maneuvers such as the administration of nitric oxide and surfactant, fluids management, corticoids ${ }^{6-8}$.

The use of prone ventilation has been shown to improve aeration and decrease alveolar shunt in an animal model ${ }^{9}$. Many clinical and experimental studies have since been carried out, but the mechanism responsible for the improvement remains highly controversial ${ }^{4,10}$.

During anesthesia and paralysis, the prone position determines a more homogeneous distribution of the gravitational gradient for alveolar inflation ${ }^{11}$.

Following aspiration other symptoms can be observed, with microvascular lung injury, hypoxemia, increase alveolar protein content and inflammatory response, etc.

The purpose of this study was to test the hypothesis whether mechanical ventilation with prone position improves arterial oxygenation and decreases local inflammatory dysfunction on an experimental model of ALI.

\section{Methods}

\section{Surgical procedure}

All procedures were approved by the Institutional Research Committee at Federal University of São Paulo, in accordance with the National Institutes of Health $(\mathrm{NIH})$ Guidelines Regarding Animal Experimentation and the principles of the Brazilian College on Animal Experimentation.

Twenty $(n=20)$ male Wistar rats weighing 280-340 g were fasted overnight with free access to water. Animals were group-housed in standard Plexiglas bins (2-3 rats per cage). Rats $(\mathrm{n}=5$ in every group) were anesthetized intraperitoneally (i.p.) with sodium thiopental $(40 \mathrm{mg} / \mathrm{kg}$ body weight; Thionembutal, ABBOTT, SP, Brazil). Muscle relaxation was maintained with $0.8 \mathrm{mg} / \mathrm{kg}$ pancuronium bromide (Pavulon, Organon, SP, Brazil) i.p. Animals were placed in the supine position, and $1 \%$ lidocaine was injected subcutaneously at the tracheal region.

After anesthesia, a tracheotomy was performed and a 14G cannula was inserted approximately $1 \mathrm{~cm}$ above the carina. A hind paw vein (used for drug infusions and compensation of fluid losses) and the left internal carotid artery (used to obtain arterial blood for gases determination) were exposed and cannulated using a PE-50 tubing (Intramedic Polyethylene Tubing, Becton Dickinson, NJ, USA). Normothermia was maintained with an underlying electric hotplate $(37 \pm 0.6 \mathrm{oC}[\text { mean } \pm \mathrm{SD}])^{1}$.

\section{Mechanical ventilation (MV)}

After reaching a surgical plane of anesthesia and muscle relaxation, the animals were ventilated using a rodent ventilator (683 model, Harvard Apparatus; MA, USA) for $3 \mathrm{~h}$ using a tidal volume $\left(\mathrm{V}_{T}\right)$ set at approximately $6 \mathrm{~mL} / \mathrm{kg}$, a positive end-expiratory pressure (PEEP) of $5 \mathrm{cmH}_{2} \mathrm{O}$, a fraction of inspired oxygen $\left(\mathrm{FiO}_{2}\right)$ of 1.0 , a respiratory rate (RR) of $30-50$ cycles per minutes and an inspiration/expiration $(\mathrm{I} / \mathrm{E})$ ratio of $1: 1$. A venous catheter was placed in the jugular vein to allow the infusion of isotonic saline solution and sodium pentobarbital whenever needed ${ }^{1}$.

The animals were divided into 4 different groups $(n=5$ in every group). The first group (CS-MV) received only conventional $\mathrm{MV}$ in supine position; the second group (CP-MV) received only conventional $\mathrm{MV}$ in prone position; the third group $(\mathrm{HCl}+\mathrm{S})$ received bilateral instillation of $\mathrm{HCl}$ and $\mathrm{MV}$ and in supine position; the fourth group $(\mathrm{HCl}+\mathrm{P})$ received $\mathrm{HCl}$ instillation and $\mathrm{MV}$ in the prone position for 180 minutes. The animals were maintained in the supine and/or prone position for 10 minutes, hereby defined as the baseline phase. In order to be included in the remainder of this study, each rat had to exhibit an initial arterial partial pressure of oxygen $\left[\mathrm{PaO}_{2}\right] \geq 300 \mathrm{mmHg}$.

\section{Acid instillation lung injury}

After 10 min connected in the ventilator for stabilization, the lung injury was performed using a $0.1 \mathrm{~N} \mathrm{HCl}$ solution $(2 \mathrm{~mL} / \mathrm{kg})$ instilled in the endotracheal tube in the supine position with the rat disconnected from the ventilator, the aspiration of $\mathrm{HCl}$ solution was performed in an inverted Trendelenburg position. When $\mathrm{PaO}_{2} \leq 150 \mathrm{mmHg}$ the protocol was started ${ }^{1}$.

\section{Measurements}

\section{Arterial blood gases measurement}

Arterial blood gases $\left(\mathrm{PaO}_{2}\right.$ and arterial partial pressure of carbon dioxide $\left[\mathrm{PaCO}_{2}\right]$ ) were determined in blood samples collected with sterile vented plastic syringes (PICO 70, Radiometer, Copenhagen, Denmark) and measured at the times acid injury, 60, 120 and 180 min using an automatic AVL-Compact3 device (Roche Diagnostic, Mannheim, Germany).

\section{Wet/dry (W/D) weight ratio of lungs}

After bronchoalveolar lavage, the right lung was placed in a drying oven for $72 \mathrm{~h}$ at $60^{\circ} \mathrm{C}$ and then re-weighed. The W/D ratios of lungs were then calculated.

\section{Bronchoalveolar lavage (BAL)}

At the end of $3 \mathrm{~h}$, the animals were euthanized $(1 \mathrm{~mL} / 100$ $\mathrm{g}$ bw T-61 Euthanasia Solution, Hoechst \& Roussel). A sternotomy was performed, and the lungs and appending structures were removed and weighed. The left lung was tied, and the right lung was washed three times with $20 \mathrm{~mL} / \mathrm{kg}$ cold sterile phosphate-buffered saline (PBS; pH 7.2-7.4). Lavage fluids were kept separate and centrifuged (at $400 \times \mathrm{g}$ for $10 \mathrm{~min}$ ) at $4^{\circ} \mathrm{C}$, and the supernatants were frozen immediately on dry ice and stored at $-80^{\circ} \mathrm{C}^{1}$. 


\section{Protein leakage}

An 1-mL aliquot of BAL was used to measure the total protein content using specific kits (QUANT-iT Protein Assay, Invitrogen, CA, USA) and a standard equipment for readings (QUBIT Fluorometer, Invitrogen, CA, USA).

\section{Cytokine assay}

TNF- $\alpha$ concentrations in BAL were determined using a rat-specific, commercially available enzyme immunoassay [ELISA] (R\&D Systems, Minneapolis, USA).

\section{Statistical analysis}

Data were expressed as means \pm standard deviation (SD). Values were compared between groups using an ANOVA test for multiple comparisons, and repeated-measures ANOVA was used to compare measurements among groups along the different time periods. Statistical analyses were performed using a standard computer software package (GraphPad Prisma, GraphPad Software, San Diego, CA, USA). $P$-values less than 0.05 were considered statistically significant.

\section{Results}

None of the animals died before the end of the experiment. The groups did not differ significantly in terms of the variables studied during the baseline period, either in terms of gas exchange, nor did the body weights differ at the end of experiment.

Between control groups (CS-MV and CP-MV) no significant differences were found concerning the studied variables. Differences could be observed after induced lung injury in groups $\mathrm{HCl}+\mathrm{S}$ and $\mathrm{HCl}+\mathrm{P}$ when compared with their respective controls (Table 1, Figures 1, 2 and 3).

\section{Blood gases analyses}

After 60 min of mechanical ventilation the $\mathrm{PaO}_{2}$ values were higher in the $\mathrm{HCl}+\mathrm{P}$ group compared with $\mathrm{HCl}+\mathrm{S}$ group (128.0 \pm 2.9 versus $110.0 \pm 6.7 \mathrm{mmHg}$, respectively). In the time point $120 \mathrm{~min}$ the $\mathrm{PaO}_{2}$ were higher in the $\mathrm{HCl}+\mathrm{P}(152.0 \pm 2.5$ $\mathrm{mmHg}$ ) compared with $\mathrm{HCl}+\mathrm{S}(146.0 \pm 4.2 \mathrm{mmHg})$ (Table 1), and the difference was observed at the time 180 min when comparing $\mathrm{HCl}+\mathrm{S}$ versus $\mathrm{HCl}+\mathrm{P}(\mathrm{P}<.001$; Table 1$)$. At the times 60, 120 and 180 minutes the $\mathrm{PaO}_{2}$ differ when compared $\mathrm{HCl}+\mathrm{S}$ and $\mathrm{HCl}+\mathrm{P}$ with respectively control group (Table 1 ). $\mathrm{PaCO}_{2}$ values were lower in the $\mathrm{HCl}+\mathrm{P}$ group compared to the $\mathrm{HCl}+\mathrm{S}$ group (Table 1) in the times 60, 120 and $180 \mathrm{~min}$. No significant differences were observed among $\mathrm{HCl}$ groups at the acid injury time point.
W/D weight of lungs, total proteins, and TNF- $\alpha$ in the BAL

W/D ratios were higher in the $\mathrm{HCl}+\mathrm{S}$ group as compared to the $\mathrm{HCl}+\mathrm{P}$ group $(P<.05$; Figure 1$)$.

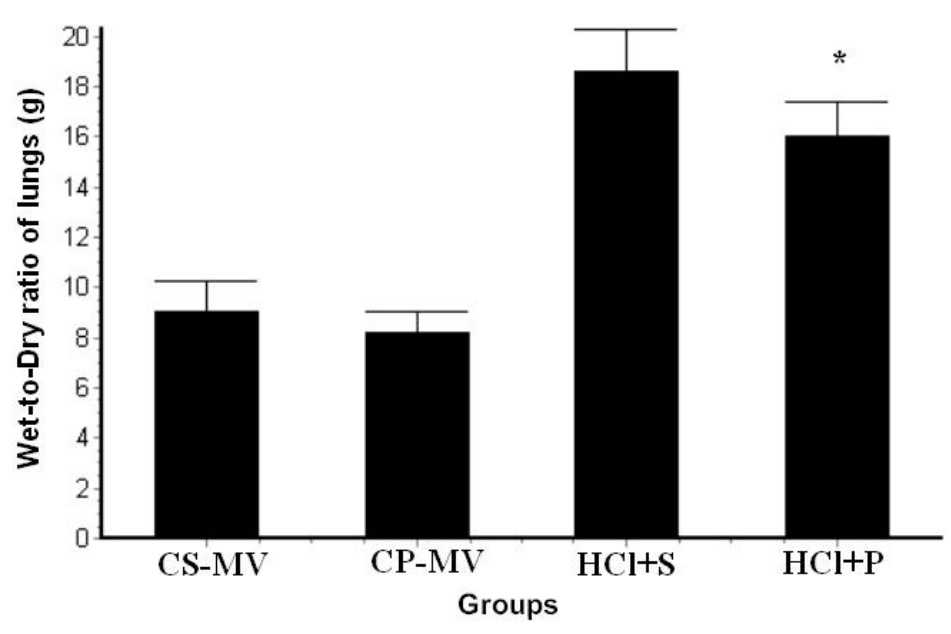

FIGURE 1 - Effect of position on lungs wet to dry ratios from rats, mechanically-ventilated controls (C-MV) and instilled with $\mathrm{HCl} .{ }^{*} P<.05$ versus the $\mathrm{HCl}+\mathrm{S}$ group. Values are presented as mean $\pm \mathrm{SD}$. Values are presented as mean $\pm \mathrm{SD}$

The total proteins in BAL were lower in the $\mathrm{HCl}+\mathrm{P}$ group compared to $\mathrm{HCl}+\mathrm{S}$ group $[38.0 \pm 2.9 \mathrm{mg} / \mathrm{mL}$ versus $47 \pm 2.3 \mathrm{mg} / \mathrm{mL}$, respectively; $P<.001]$. In the CS-MV group and in CP-MV, the total protein values in BAL were $26.0 \pm 1.6 \mathrm{mg} / \mathrm{mL}$ and $23.0 \pm 2.3 \mathrm{mg} / \mathrm{mL}$, respectively (Figure 2). 


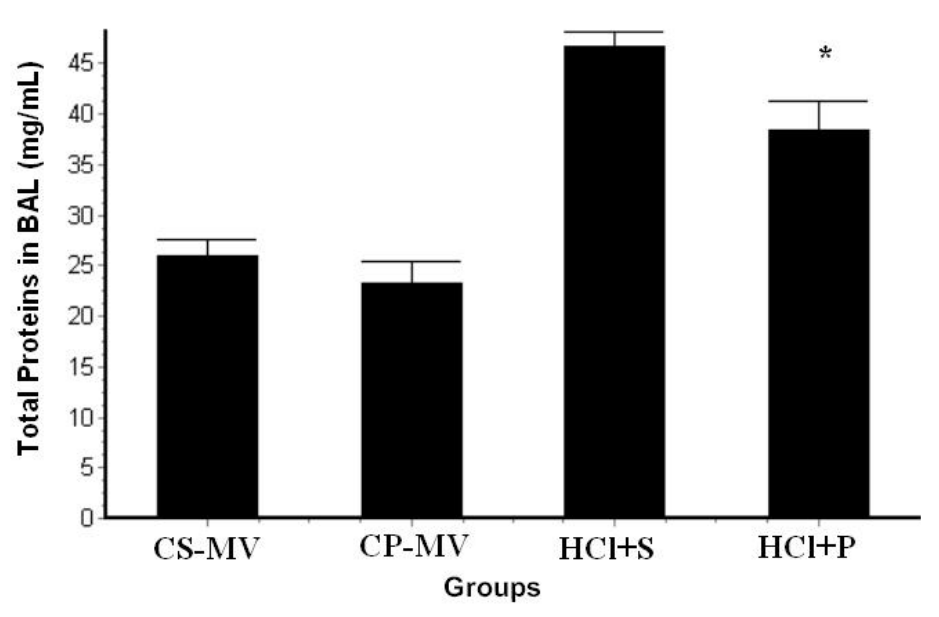

FIGURE 2 - Effect of position on total protein levels in BAL from rats, mechanically-ventilated controls (C-MV) and instilled with $\mathrm{HCl} .{ }^{*} P<0.05$ versus the $\mathrm{HCl}+\mathrm{S}$ group. Values are presented as mean $\pm \mathrm{SD}$

The TNF- $\alpha$ concentration in BAL was significantly higher in the group $\mathrm{HCl}+\mathrm{S}$ and $\mathrm{HCl}+\mathrm{P}$ when compared with the respective control group $(P<.001)$, but did not differ between $\mathrm{HCl}$-injured groups (Figure 3 ).

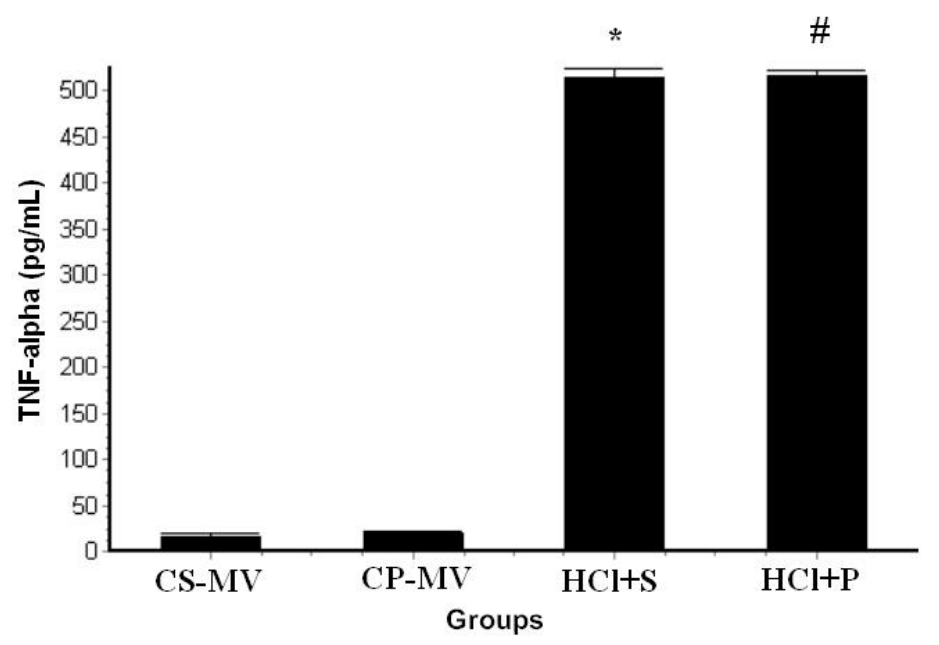

FIGURE 3 - Effect of position on TNF- $\alpha$ levels in BAL from rats, mechanically-ventilated controls (C-MV) and instilled with $\mathrm{HCl} . * P<0.05$ versus the CS-MV group, and $\# P<.05$ versus the CP-MV group. Values are presented as mean $\pm \mathrm{SD}$

\section{Discussion}

The present study confirm that prone position promoted the recovery of $\mathrm{PaO}_{2}$ after $\mathrm{HCl}$ instillation. Decreased levels of total proteins in BAL accompained this alleviating effect on lung injury.
Since West's accurate descriptions of the physiology of respiration and the ventilation/perfusion zones ${ }^{12}$, position change has been advocated to promote redistribution of gas, recruit alveoli, and redistribute pulmonary blood flow ${ }^{13}$.

Prone position was initially introduced in healthy anesthetized and paralyzed subjects for surgical specific reasons. Since then, it has been used during acute respiratory failure to improve gas exchange. The interest on prone position during ALI/ARDS progressively increased, even if the mechanisms leading to a respiratory improvement are not yet completely understood. Our results demonstrated the ameliorating effect on the recovery gas exchange in the group with lung injury and ventilated in the prone position.

Reports of prone positioning to improve oxygenation in patients with ALI/ARDS date back nearly 30 years ${ }^{14}$. Animal studies have demonstrated improved oxygenation and ventilation perfusion ratios, along with restoring aeration, decreasing shunt, and preserving perfusion ${ }^{1,9,15}$. In addition, prone positioning has been shown to eliminate compression of the lungs by the heart ${ }^{16}$.

TNF- $\alpha$ is an early-response, pro-inflammatory cytokine that has been shown to be integral in the pathogenesis of other lung injury models that are neutrophil-mediated ${ }^{17-20}$. TNF- $\alpha$ leads to activation of leukocytes and induces the expression of endothelial adhesion molecules that play a major role in the leukocyte-endothelial interactions that lead to neutrophil migration into the alveoli ${ }^{21}$. Our results demonstrated a small reduction in the TNF- $\alpha$ levels in the group $\mathrm{HCl}+\mathrm{P}$, but these effects did not differ significantly in comparison with the HCL $+\mathrm{S}$ group.

Computerized tomography of the chest shows that, while ARDS injuries are heterogeneous, they primarily affect the dorsal regions of the lungs ${ }^{22}$. Therefore, in the supine position, pulmonary ventilation without PEEP is primarily distributed to the ventral region of the lungs. The ratio of ventilation between ventral and dorsal regions is around 2.5:1. With the addition of PEEP, the distribution of ventilation becomes progressively more homogeneous. It means that ratio of close to 1:1 with PEEP at $20 \mathrm{cmH}_{2} \mathrm{O}^{23}$.

\section{Conclusion}

The use of the prone position improves arterial oxygenation and reduces the lung edema in a rat model of acid injury.

\section{References}

1. Oliveira-Júnior IS, Maghanin CC, Carbonel AAF, Monteiro CMR, Cavassani SS, Oliveira-Filho RM. Effects of pentoxyfilline on TNF-alpha and lung histopatology in HCl-induced lung injury. Clinics. 2008;39:77-84. 2. Moore FA, Moore EE, Read RA. Postinjury multiple organ failure: role of extrathoracic injury and sepsis in adult respiratory distress syndrome. New Horiz. 1993; 1:538-49.

3. Treggiari MM, Hudson LD, Martin DP, Weiss NS, Caldwell E, Rubenfeld G. Effect of acute lung injury and acute respiratory distress syndrome on outcome in critically ill trauma patients. Crit Care Med. 2004;32:327-31. 4. [No authors listed]. Ventilation with lower tidal volume as compared with traditional tidal volumes for acute lung injury and the acute respiratory distress syndrome: the acute respiratory distress syndrome network. N Engl J Med. 2000;342:1301-8. 
5. Severansky JE, Levy MM, Marini JJ. Mechanical ventilation in sepsis-induced acute lung injury/acute respiratory distress syndrome: an evidence based review. Crit Care Med. 2004;32:S548-53.

6. Krause M, Olsson T, Law AB, Parker RA, Lindstrom DP, Sundell HW, Cotton RB. Effect of volume recruitment on response to surfactant treatment in rabbits with lung injury. Am J Respir Crit Care Med. 1997;156:862-6.

7. Cheng IW, Matthay MA. Acute lung injury and the acute respiratory distress syndrome. Crit Care Clin. 2003;19:693-712.

8. Huang TK, Uyehara CF, Balaraman V, Miyasato CY, Person D, Egan E, Easa D. Surfactant lavage with lidocaine improves pulmonary function in piglets after HCL-induced acute lung injury. Lung. 2004;182:15-25.

9. Richter T, Bellani G, Scott Harris R, Vidal Melo MF, Winkler T, Venegas JG, Musch G. Effect of prone position on regional shunt, aeration and perfusion in experimental acute lung injury. Am J Respir Crit Care Med. 2005;172:480-7.

10. Pelosi P, Brazzi L, Gattinoni L. Prone position in acute respiratory distress syndrome. Eur Respir J. 2002;20:1017-28.

11. Pelosi P, Caironi P, Taccone P, Brazzi L. Pathophysiology of prone positioning in the healthy lung and in ALI/ARDS. Minerva Anesthesiol. 2001;67:238-47.

12. West JB. Respiratory physiology: the essentials. Baltimore: Williams and Wilkins; 1979.

13. Servillo G, Roupie E, De Robertis E, Rossano F, Brochard L, Lemaire $F$, Tufano R. Effects of ventilation in ventral decubitus position on respiratory mechanics in adult respiratory distress syndrome. Intens Care Med. 1997;23:1219-24.

14. Douglas WW, Rehder K, Beynen FM, Sessler AD, Marsh HM. Improved oxygenation in patients with acute respiratory failure: the prone position. Am Rev Respir Dis. 1977;115:559-66.

15. Lamm WJ, Graham MM, Albert RK. Mechanism by which the prone position improves oxygenation in acute lung injury. Am J Respir Crit Care Med. 1994;150:184-93.
16. Albert RK, Hubmayr RD. The prone position eliminates compression of the lungs by the heart. Am J Respir Crit Care Med. 2000;161:1660-5. 17. Trezena AG, Silva ZL, Oliveira-Filho RM, Damazo AS, Straus AH, Takahashi HK, Oliani SM, Tavares de Lima W. Differential regulation of the release of tumor necrosis factor- $\alpha$ and of eicosanoids by mast cells in rat airways after antigen challenge. Mediat. Inflam. 2003; 12:237-46.

18. Cavriani G, Domingos HV, Soares AL, Trezena AG, Ligeiro-Oliveira AP, Oliveira-Filho RM, Sudo-Hayashi LS, Tavares de Lima W. Lymphatic system as a path underlying the spread of lung and gut injury after intestinal ischemia/reperfusion in rats. Shock. 2005;23:330-6.

19. Cavriani G, Domingos HV, Oliveira-Filho RM, Sudo-Hayashi LS, Vargaftig BB, Tavares de Lima W. Lymphatic thoracic duct ligation modulates the serum levels of IL-1 $\beta$ and IL-10 after intestinal ischemia/ reperfusion in rats with the involvement of tumor necrosis factor $\alpha$ and nitric oxide. Shock. 2007;27:209-13.

20. Oliveira APL, Domingos HV, Cavriani G, Damazo AS, Franco ALS, Oliani SM, Oliveira-Filho RM, Vargaftig BB, Tavares de Lima W. Cellular recruitment and cytokine generation in a rat model of allergic lung inflammation are differentially modulated by progesterone and estradiol. Am J Physiol Cell Physiol. 2007;293:C1120-8.

21. Davidson BA, Knight RP, Hekinski JD, Nader ND, Shanley TP, Johnson KJ. The role of tumor necrosis factor- $\alpha$ in the pathogenesis of aspiration pneumonitis in rat. Anesthesiology. 1999;91:486-99.

22. Gattinoni L, Pelosi P, Suter PM, Pedoto A, Vercesi P, Lissoni A. Acute respiratory distress syndrome caused by pulmonary and extrapulmonary disease: different syndromes? Am J Respir Crit Care Med. 1998;158:3-11.

23. Johansson MJ, Wiklund A, Flatebo T, Nicolaysen A, Nicolaysen G, Walther SM. Positive end-expiratory pressure affects regional redistribution of ventilation differently in prone and supine sheep. Crit Care Med. 2004;32:2039-44.

\section{Correspondence:}

Itamar Souza de Oliveira-Júnior

Rua Pedro de Toledo, 781/11 andar

04039-032 São Paulo - SP Brazil

Phone: (55 11)9328-4975

souza.oliveira@unifesp.br

ijuniors@hotmail.com

Conflict of interest: none

Financial source: FAPESP

(process number 06/60834-9)

Received: March 25, 2008

Review: May 27, 2008

Accepted: June 24, 2008

\section{How to cite this article}

Oliveira WRS, Silva I, Simões RS, Fuchs LFP, Oliveira-Filho RM, Oliveira-Júnior IS. Effects of prone and supine position on oxygenation and inflammatory mediator in a hydrochloric acid-induced lung dysfunction in rats. Acta Cir Bras. [serial on the Internet] 2008 Sept-Oct;23(5). Available from URL: http://www.scielo.br/acb 